CARADDE: Jurnal Pengabdian Kepada Masyarakat
$\begin{gathered}\text { https://journal.ilininstitute.com/index.php/caradde } \\ \text { Volume 2 I Nomor 1 I Agustus |2019 } \\ \text { e-ISSN: 2621-7910 dan p-ISSN: 2621-7961 }\end{gathered}$

\title{
Pengolahan Buah Naga Kelompok Bulo ( Badan Usaha Lorong ) Teratai Putih
}

\author{
Musdalifah $^{1}$, Arwin Arif ${ }^{2}$, Fandi Ahmad ${ }^{3}$
}

Keywords :

Buah Naga;

Diversifikasi Produk;

Pengemasan;

Labelling.

\section{Corespondensi Author}

Pendidikan Ekonomi dan Biologi, STKIP Pembangunan Indonesia

Jalan Inspeksi Kanal Citraland No.10

Email: x_ivha@yahoo.com

\section{History Artikel}

Received: Juni-2019;

Reviewed: Juli -2019

Accepted: Agustus-2019

Published: Agustus-2019
Abstrak. Tujuan program kemitraan masyarakat stimulus adalah (1) mengubah mindset kelompok Badan Usaha Lorong (Bulo) Teratai Putih, (2) melatih kelompok Badan Usaha Lorong (Bulo) Teratai Putih dalam mendiversifikasi buah naga menjadi beberapa produk yang bernilai ekonomi, (3) menerapkan cara pengemasan dan labelling. Pelaksanaan program kemitraan masyarakat stimulus menggunakan 3 (tiga) metode yaitu (1) metode parsitipasi aktif, (2) metode diversifikasi produk dan (3) metode pengemasan dan labelling. Hasil kegiatan pengabdian dari evaluasi penilaian kepuasan masyarakat dalam mengikuti kegiatan sosialisasi berupa penjelasan mengenai pengolahan buah naga sebesar 79,14\%. Hal ini menandakan masyarakat berparsitipasi aktif dan mampu memotivasi jiwa wirausaha mereka dalam mengolah buah naga menjadi lahan bisnis. Selain itu, evaluasi pengolahan buah naga menjadi selai buah naga (40,91\%), mie buah naga (34,85\%) dan keripik kulit buah naga $(24,24 \%)$. Dari 3 (tiga) produk yang dihasilkan selai buah naga menjadi primadona karena selain pembuatannya yang mudah, rasanya juga tak kalah dengan selai yang ada dipasaran. Sementara, proses pengepakan (60,83\%) dan labeling (39,17\%), dari hasil evaluasi penilaian masyarakat memang agak kesulitan ditahap pembuatan label karena butuh alat dan kreativitas dalam merancang suatu label usaha.

\section{PENDAHULUAN}

Salah satu sektor yang sangat berpengaruh dalam pertumbuhan ekonomi di Sulawesi Selatan adalah sector pertanian. Sektor pertanian ini memiliki beberapa subsector yang menjadi sumber pemenuhan konsumsi masyarakat sekaligus menjadi mata pencaharian dalam perdagangan. Salah satu tanaman hortikultura yang lagi trend dan menarik dibudidayakan di Kota Makassar adalah tanaman buah naga (dragon fruit).
Buah naga (dragon fruit) merupakan salah satu tanaman hortikultura yang baru dibudidayakan di Indonesia dengan warna buah merah yang menyala dan bersisik hijau (Khairunnas \& Tety, 2011). Buah ini memiliki bentuk yang sangat unik dan cukup memikat untuk dilihat. Bentuk fisiknya mirip dengan buah nanas hanya saja buah ini memiliki sulur pada kulitnya. Buah naga berwarna merah jambu dengan daging buah berbagai jenis antara lain berwarna putih, kuning dan merah dengan biji kecil berwarna hitam yang sangat lembut dan lunak (Mahmudi, 2011). 
Menurut Emil (2011), tanaman buah naga tumbuh dengan baik didaerah yang memiliki curah hujan $2000 \mathrm{~mm} /$ tahun. Tanaman buah naga lebih menyukai kondisi kering dibandingkan basah (lembab). Tetapi buah naga masih dapat tumbuh pada curah hujan yang tinggi (sekitar 1.000- 1.300 $\mathrm{mm} /$ tahun. Pertumbuhan tanaman buah naga memerlukan intensitas matahari penuh yang dibutuhkan sekitar $80 \%$, suhu udara ideal untuk tanman buah naga berkisar $26-36^{\circ} \mathrm{C}$. dengan kelembaban 70- 90. Tanah harus berareasi baik dan derajat keasaman $(\mathrm{pH})$ tanah yang disukai bersifat sedikit alkalis (Kristanto, 2009).

Menurut Rahmawati (2013), pengemasan merupakan salah satu cara untuk melindungi atau mengawetkan produk pangan maupun non-pangan. Kemasan adalah suatu wadah atau tempat yang digunakan untuk mengemas suatu produk yang dilengkapi dengan label atau keterangan - keterangan termasuk beberapa manfaat dari isi kemasan. Pengemasan mempunyai peranan dan fungsi yang penting dalam menunjang distribusi produk terutama yang mudah mengalami kerusakan.

Kelurahan Laikang Kecamatan Biringkanaya Kota Makassar yang berada di ujung bagian bawah Kota Makassar memiliki salah satu kelompok badan usaha lorong yang dibentuk melalui program BUlo ini sejak tahun 2016. Kelompok masyarakat ini dinamakan sebagai Kelompok Badan Usaha Lorong (BUlo) Teratai Putih. Menurut Nurfahmiati (2018), kelompok ini melakukan pembudidayaan tanaman holtikultura seperti cabe, sayur, tomat, kacang-kacangan, termasuk buah naga dan lain-lain. Pembudidayaan ini memiliki lokasi sendiri di kawasan kelurahan Laikang dengan ukuran cukup luas untuk tanaman holtikultura yang kemudian diberi nama "Green House". Berkaitan dengan keberadaan buah naga di kelurahan ini, jumlah buah naga di Green House sangat terbatas. Sementara buah naga banyak terlihat jika kita melewati depan rumah masyarakat di Kawasan Kelurahan Laikang RT 002/ RW 010. Kebanyakan masyarakat menanam buah naga sebagai pelengkap hiasan rumah di kebun-kebun depan rumah mereka. Sehingga keberadaan buah naga, terkadang hanya dijadikan sebagai pelengkap konsumsi saja apabila sudah berbuah. Pertama kali harga buah naga di tingkat petani yaitu tahun 2011 berkisar antara Rp 25.000 - Rp 30.000 per kg dan sekarang harganya berkisar Rp $10.000-$ $\mathrm{Rp} 15.000$ per $\mathrm{kg}$. Menurut Penelitian yang dilakukan Setiawan dan Soelistyo (2017), ratarata pendapatan petani sebesar $\mathrm{Rp}$. 282.440.750 dan nilai produksi pada titik impas (Break Event Poin) petani buah naga di Desa Sambirejo sebesar $14.353 \mathrm{Kg}$, maka dapat disimpulkan bahwasannya usaha ini layak dijalankan. Dari hasil penelitian tersebut, harga buah naga masih tergolong rendah jika harganya Rp. $15.353 / \mathrm{kg}$. Hal ini disebabkan karena, banyak masyarakat yang membudidayakan saja tapi tidak bisa melakukan pengolahan lanjutan agar bisa menghasilkan berbagai jenis produk inovatif yang bernilai ekonomi. Padahal prospek buah naga dengan inovasi-inovasi yang menarik sangat berpeluang dalam bersaing di pasar lokal. Namun, peluang usaha produk olahan buah naga masih terbuka lebar di daerah ini karena buah naga mempunyai beberapa kelebihan dibandingkan dengan buah-buahan yang lain, yaitu mempunyai khasiat yang bermanfaat bagi kesehatan manusia.

Pengembangan budidaya tanaman buah naga apabila diprioritaskan di Kelurahan Laikang sangat memiliki potensi untuk dikembangkan baik dari segi produksi maupun pemasaran. Hal ini disebabkan karena keberadaan kelompok ini cukup aktif dalam setiap kegiatan kemasyarakatan, sehingga sangat mudah dalam melakukan promosi apabila ada kegiatan yang dilaksanakan.

Adapun masalah dalam kegiatan ini adalah 1) masalah pertama tentang pengetahuan masyarakat yang masih rendah tentang budidaya buah naga, manfaat buah naga bagi kesehatan tubuh serta cara pemeliharaan buah naga yang terkadang sulit berbuah atau bahkan buahnya cepat jatuh sebelum dipanen. Beberapa penjelasanpenjelasan teknis ini akan disampaikan oleh tim kami melalui pendekatan pola pikir masyarakat, sehingga masyarakat bisa mengetahui secara luas keberadaan buah naga yang memiliki manfaat sangat besar, 2|) masalah kedua tentang pengetahuan dan keterampilan dalam mengolah buah naga menjadi berbagai macam produk yang bernilai ekonomi. Pengolahan buah naga sebagai bentuk diversifikasi produk ini akan diolah menjadi tiga produk utama yaitu keripik buah 
naga dari kulit buah naga, mie dan selai buah naga dari daging buah naga. Masalah ini akan kami lakukan pendekatan pelatihan olahan buah naga bagi kelompok masyarakat tersebut, 3) masalah ketiga tentang pengemasan dan labelling bagi produk yang siap konsumsi. Setelah buah naga diolah dan siap dikonsumsi, apabila dibiarkan tanpa dikemas dengan baik, maka produk tersebut akan cepat rusak dan tidak bisa disimpan lama. Dalam mengatasi hal tersebut, tim kami akan melakukan pendekatan pelatihan pengemasan dan lebelling sehingga selain masyarakat diajarkan tentang pelatihan pengolahan buah naga, masyarakat juga akan diberikan pengetahuan dan keterampilan tentang cara melakukan pengemasan bagi produk sehingga bisa tahan lama, sekaligus mengajarkan tentang cara membuat label bagi produk yang telah dihasilkan.

Melihat permasalahan yang dihadapi, maka perlu ditindaklanjuti melalui kegiatan ipteks ini dengan memberikan pelatihan pengolahan buah naga. Hal ini berkaitan dengan hasil pengabdian yang dilakukan Hidayat dkk (2018) mengenai "Ibm Pengolahan Buah Naga Sebagai Upaya Meningkatkan Nilai Tambah Dan Pengendalian Harga Buah Naga. Selain itu, hasil pengabdian yang dilakukan Chayati dan Ratnaningsih ( 2010) mengenai "Teknologi Pengolahan Buah Naga dan Diversifikasi Produk Olahannya Sebagai Upaya Peningkatan Jiwa Kewirausahaan" juga menjadi dasar dalam pelaksanaan kegiatan pengabdian ini. Rata-rata dalam hasil pengabdian, buah naga diolah menjadi sirup, es cream, jus, permen, dan stik buah naga sehingga Tim mencoba untuk mengolah buah naga menjadi mie buah naga, selai buah naga dan keripik kulit buah naga.

\section{METODE}

Adapun metode pelaksanaan yang akan dilakukan adalah metode parsitipasi aktif merupakan kegiatan yang dilakukan dengan cara memberikan penjelasan tentang karakteristik tanaman buah naga, Dalam metode ceramah, ada beberapa langkahlangkah yang dilakukan yaitu (a) melakukan persentasi materi (b) membuka sesi diskusi dan pemberian kesempatan kepada peserta untuk mengajukan pertanyaan.
Metode diversifikasi produk olahan buah naga merupakan kegiatan yang dilakukan dengan cara demonstrasi terhadap produk yang akan dibuat. Ada beberapa langkah yang dilakukan adalah (1) tahap persiapan, dimana bahan dan alat dalam membuat produk ( keripik buah naga, selai buah naga dan mie buah naga) dipersiapkan, (2) tahap proses, dalam demonstrasi, peserta diberikan kesempatan bertanya langsung pada saat proses diversifikasi produk dilakukan, (3) tahap penutup, dalam tahap ini produk yang telah selesai siap untuk dikonsumsi langsung atau bisa dilanjutkan ke metode selanjutnya agar bernilai ekonomi.

Metode pengemasan dan labelling merupakan kegiatan yang dilakukan dengan tujuan produk yang telah selesai didiversifikasi memiliki nilai jual di pasar lokal. Langkah-langkah dalam pengemasan adalah a) pemilihan bahan pengepakan yang disesuaikan dengan produk, seperti keripik buah naga akan dikepak dalam bentuk plastic, selai dikepak dalam bentuk kaleng atau kaca, mie buah naga dikepak dalam aluminum, b) Penyegelan adalah upaya mengunci produk dalam pengepakan (kemasan) untuk masa berlaku tertentu. Sedangkan, langkah-langkah dalam labelling produk adalah memberi label berupa informasi singkat mengenai produk tersebut yang terdiri dari a) nama produk, b) pembuat produk, c) alamat pembuat produk, d) bahan yang digunakan untuk membuat produk, e) komposisi zat gizi produk, f) masa kadaluarsa, g) izin depkes atau instansi terkait, misalnya informasi halal labeling.

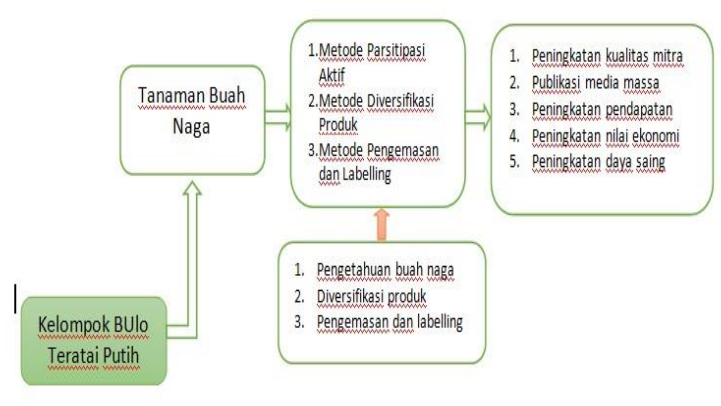

Gambar 1 : Alur Metode Pengabdian 
Caradde: Jurnal Pengabdian Kepada Masyarakat

Vol 2 No 1, Agustus 2019

\section{HASIL DAN PEMBAHASAN}

\section{A. Pelaksanaan Sosialisasi}

Kegiatan pengabdian dalam rangka pengolahan buah naga menjadi beberapa produk didahului dengan pemberian sosialisasi tentang asal muasal kemunculan buah naga di Indonesia sampai pembahasan mengenai pentingnya mengkonsumsi buah naga. Pelaksanaan sosialisasi ini bertujuan agar masyarakat mengetahui terlebih dahulu manfaat buah naga sehingga termotivasi untuk mengkonsumsi, bahkan dijadikan sebagan lahan pendapatan. Sosialisasi ini terdiri dari 2 ( dua ) materi yaitu materi pertama dengan melihat sudut pandang biologi, dimana dijelaskan tentang sejarah buah naga, jenisjenis buah naga sampai manfaatnya untuk kesehatan manusia. Selain itu, materi ke dua dengan melihat sudut pandang ekonomi, dimana dijelaskan tentang pengolahan buah naga bisa diubah menjadi beberapa produk yang bernilai ekonomi yaitu mie buah naga, selai buah naga dan keripik kulit buah naga. Ketiga produk ini merupakan hasil pengolahan buah naga pada kegiatan pengabdian ini, namun tidak menutup kemungkinan buah naga bias diolah menjadi beberapa produk lainnya seperti teh kulit buah naga, jus buah naga, masker buah naga dan lain-lain.

Kegiatan sosialisasi ini, dilaksanakan beberapa tahap dengan dihadiri oleh 28 peserta yang merupakan anggota Badan Usaha Lorong ( Bulo ) Teratai Putih di Kelurahan Laikang Kota Makassar. Tahapan ini terdiri dari pemberian penjelasan, demonstrasi, pelatihan dan evaluasi. Pemberian penjelasan yakni dengan pemberian materi-materi, dilanjutkan dengan demonstrasi oleh tim dibantu oleh teknisi. Setelah demontrasi, kegiatan pelatihan pengolahan buah naga dilaksanakan secara bertahap mulai dari pembuatan selai buah naga, mie buah naga dan keripik kulit buah naga. Setelah itu, tim mengevaluasi hasil pelatihan yang dilakukan oleh peserta.

Dalam kegiatan ini, pada umumnya dihadiri oleh ibu-ibu rumah tangga yang tertarik untuk mengetahui lebih lanjut manfaat buah naga dan proses pengolahannya. Para peserta terlihat sangat antusias dan aktif dalam memberikan pertanyaan kepada pemateri.

Pelaksanaan sosialiasai dapat dilihat pada gambar dibawah ini,

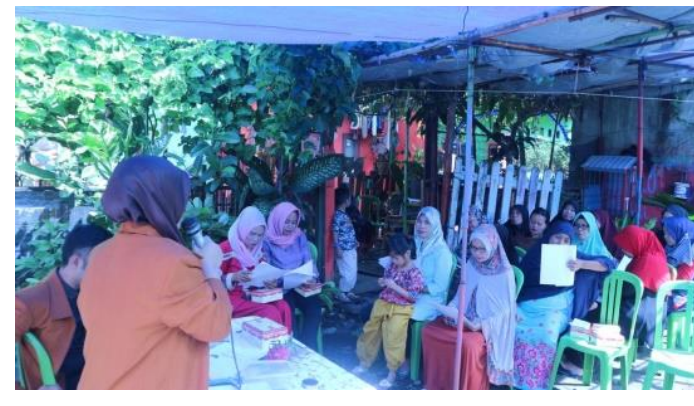

Gambar 2 : Penjelasan Materi

Sebelum dievaluasi, kuesioner harus diuji tingkat validitas dan reliabilitasnya Menurut Azwar (2014), validitas merupakan ketepatan dan kecermatan suatu alat ukur dalam melakukan fungsi ukurnya. Sedangkan, menurut Arikunto (2011), reliabilitas adalah suatu instrument yang digunakan sebagai alat pengumpul data. Adapun hasil evaluasi penilaian yang dilakukan oleh peserta berdasarkan kepuasan mengikuti kegiatan pengabdian, dapat dilihat dari gambar dibawah ini,

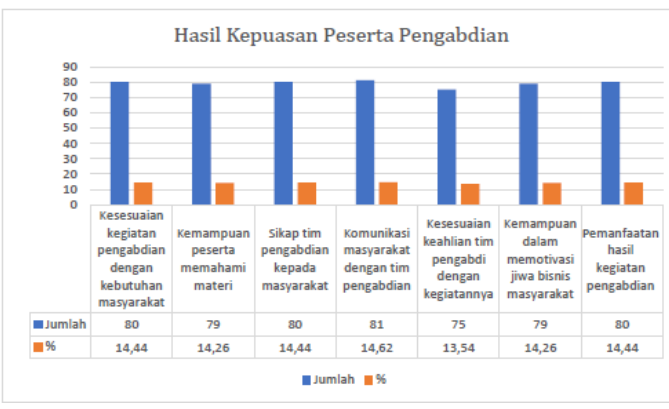

\section{Grafik 1 : Hasil Evaluasi Kepuasan Peserta}

Hasil kegiatan pengabdian dari evaluasi penilaian kepuasan masyarakat dalam mengikuti kegiatan sosialisasi berupa penjelasan mengenai pengolahan buah naga sebesar 79,14\%. Hal ini menandakan masyarakat berparsitipasi aktif dan mampu memotivasi jiwa wirausaha mereka dalam mengolah buah naga menjadi lahan bisnis.

\section{B. Praktek Pengolahan Buah Naga}

Setelah pelaksanaan sosialisasi, kegiatan dilanjutkan dengan praktek 
pengolahan naga menjadi beberapa produk yaitu selai buah naga, mie buah naga dan keripik buah naga.

1. Produk Selai Buah Naga

a. Daging buah naga yang telah matang di hancurkan dengan cara diulek (jangan diblender) agar tetap mendapatkan tekstur dari buah naga

b. Setelah diulek masukkan ke dalam teflon kemudian diaduk dengan api kecil

c. Masukkan air gula putih sambil terus diaduk sampai mengental

d. Setelah mengental masukkan air jeruk lemon secukupnya sampai rata

e. Kemudian tiriskan dan dinginkan

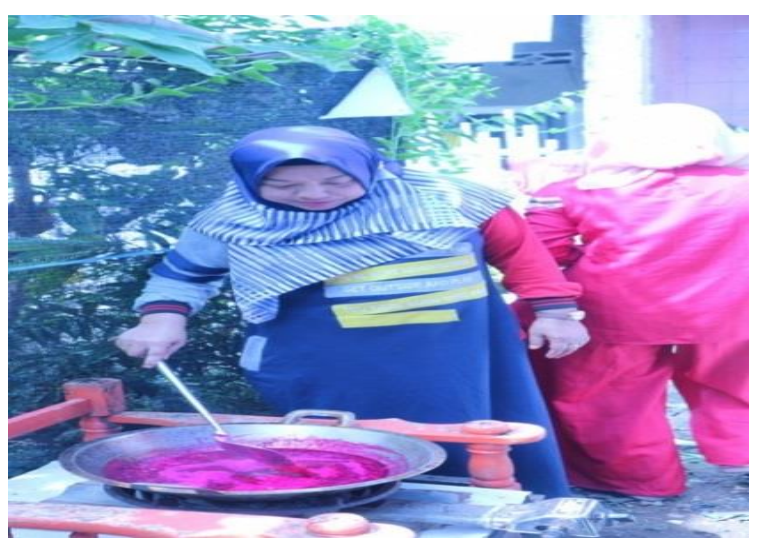

Gambar 3. Pengolahan Selai

Dalam pengolahan selai buah naga, rasa yang dihasilkan hampir sama dengan rasa pada selai strawberry. Memiliki aroma yang kuat, warna pink tua, dan bij hitam buah naga menjadikan teksturnya agak kasar tapi tidak mempengaruhi tingkat rasa yang dihasilkan. Selai buah naga ini menjadi primadona dari masyarakat karena rasanya yang enak.

2. Produk Mie Buah Naga

a. Buah naga yang telah matang dipisahkan antara kulit dan daging buah naga

b. Daging buah naga dihancurkan dengan cara diblender

c. Selanjutnya buah naga yang telah diblender dicampur dengan terigu, tepung tapioca, minyak goreng, air dan garam secukupnya

d. Setelah dicampur, dimasukkan ke dalam mesin penggiling mie

e. Hasil gilingan tersebut kemudian direbus menggunakan air dan siap dikonsumsi.

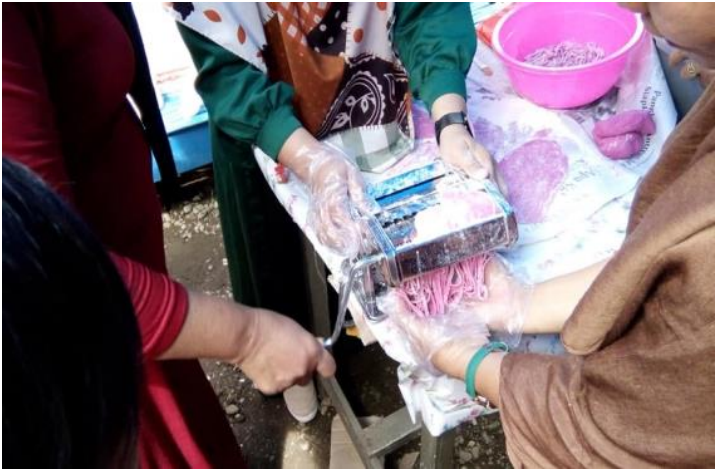

Gambar 4. Pengolahan Mie

Diantara 3 produk yang dibuah, mie buah naga merupakan produk yang tingkat kesulitannya cukup siginifikan. Adonan yang dibuat, harus memiliki standard pengolahan yang bagus karena ketika tidak sesuai takaran, maka mie yang dihasilkan tidak akan jadi. Dalam pengolahan mie buah naga, factor penghambatnya adalah pasta maker atau penggiling mie yang terkadang tidak sesuai dengan takaran adonan sehingga mie yang dihasilkan terkadang keriting dan tekstur tidak bagus. Akan tetapi, rasa dari mie buah naga ini cukup enak karena memiliki aroma buah naga dan warnanya yang unik jika disajikan.

3. Produk Keripik Kulit Buah Naga

a. Kulit buah naga menjadi keripik buah naga

b. Buah naga yang telah matang dipisahkan antara kulit dan daging buah naga

c. Kulit buah naga dibersihkan kemudian dipotong-potong sesuai selera

d. Selanjutnya kulit buah naga yang telah dipotong direndam dengan air gula, garam dan kapur secukupnya selama 3 jam.Setelah itu kulit buah naga ditiriskan kemudian dijemur sampai kering

e. Setelah dijemur, kulit buah naga yang sudah kering digoreng dengan menggunakan gula sehingga bercampur.

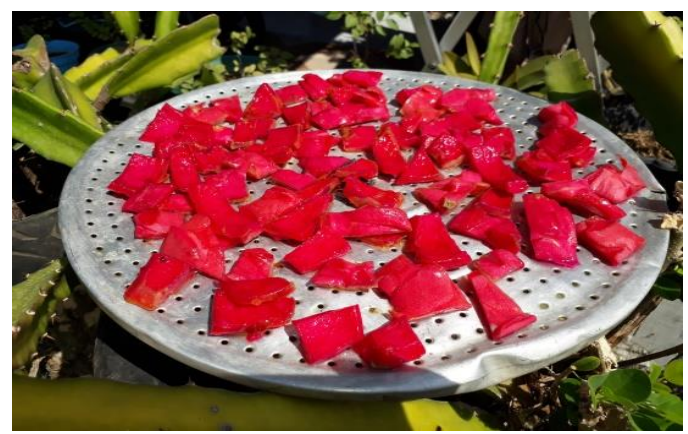

Gambar 5. Pengolahan Keripik 
Caradde: Jurnal Pengabdian Kepada Masyarakat Vol 2 No 1, Agustus 2019

Keripik kulit buah naga merupakan produk yang memiliki proses cukup lama karena ada beberapa tahap yang dilewati. Mulai dari proses perendaman, pengeringan dan penggorengan. Ada beberapa yang harus diperhatikan dalam proses pengolahan kripik kulit buah naga adalah proses perendaman kapur tidak boleh terlalu lama karena akan pahit, proses pengeringan tidak boleh terlalu lama karena akan keras jika digoreng. Rasa dari keripik buah naga ini cukup enak dan warnanya akan berubah menjadi agak kecoklatan jika sudah digoreng. Namun demikian, pembuatan keripik kulit buah naga ini masih memerlukan beberapa proses maksimal agar menghasilkan produk yang lebih enak dan gurih.

Dalam proses pembuatan 3 produk ( selai buah naga, mie buah naga dan keripik kulit buah naga memiliki factor pendukung dan factor penghambat.

Faktor yang mendukung kegiatan pengabdian ini berdasarkan hasil observasi dan tanya jawab dengan peserta adalah pada umumnya peserta belum pernah memperoleh pelatihan pengolahan buah naga menjadi beberapa produk sehingga dapat menambah pengetahuan para peserta. Disamping itu, feed back atau umpan balik antara tim pengabdian dengan peserta pelatihan sangat baik sehingga memperlancar koordinasi pelaksanaan kegiatan.

Faktor penghambat dari kegiatan pengabdian ini adalah kesulitan untuk mendapatkan bahan utama yaitu buah naga. Hal ini disebabkan musim buah naga sudah lewat yaitu sekitar bulan Januari sampai April, sementara kegiatan dilaksanakan bulan Juni. Selain itu, produk buah naga yang direncanakan ada tiga jenis yaitu selai buah naga, mie buah naga dan keripik buah naga.

Adapun hasil evaluasi penilaian terhadap rasa produk buah naga dapat dilihat pada grafik dibawah ini,

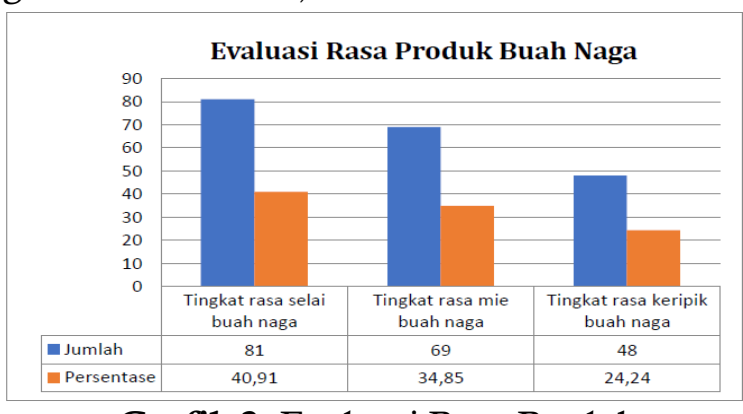

Grafik 2: Evaluasi Rasa Produk
Evaluasi pengolahan buah naga menjadi selai buah naga $(40,91 \%)$, mie buah naga $(34,85 \%)$ dan keripik kulit buah naga $(24,24 \%)$. Dari 3 (tiga) produk yang dihasilkan selai buah naga menjadi primadona karena selain pembuatannya yang mudah, rasanya juga tak kalah dengan selai yang ada dipasaran. Sedangkan keripik buah naga memiliki banyak hambatan karena prosesnya yang cukup lama dan proses penggorengan kurang memadai sehingga hasilnya tidak maksimal dan memperoleh evaluasi $24,24 \%$ dari peserta.

\section{Pengepakan dan Labelling}

1. Produk Selai Buah Naga

Sementara, produk selai buah naga sangat cocok dikemas dalam botol plastik atau botol kaca. Bahan yang digunakan adalah bahan yang dapat menyumbat botol sehingga memberi perlindungan terhadap gangguan dan pencemaran dari luar. Pada produk ini harus menggunakan tutup plastik kaku dank eras karena penggunaan tutup tersebut akan memudahkan konsumen dalam membuka kemasan dibandingkan dengan tutup botol yang fleksibel. Setelah itu, diberikan label pada produk.

2. Produk Mie Buah Naga

Bahan yang bagus untuk mengemas mie buah naga adalah menggunakan plastik atau aluminium foil. Pengemasan mie buah naga hamper sama dengan pengemasan keripik buah naga. Setelah dikemas, teknik pengemasan harus menggunakan sealing. Masa ketahanan mie buah naga hampir sama dengan mie basah pada umumnya. Mie buah naga memiliki ketahanan selama 2 atau 3 hari tapi bisa mencapai 1 bulan jika dimasukkan kedalam lemari pendingin. Selanjutnya diberikan label.

\section{Produk Keripik Buah Naga}

Bahan yang bagus untuk mengemas keripik buah naga adalah plastik. Jenis plastik kemasan memiliki banyak jenis, yang penting kemasan tidak menembus udara dan tidak terkontaminasi sehingga dapat merubah rasa dan bentuk keripik. Setelah dikemas, jika bahannya plastik, teknik pengemasan harus menggunakan sealing. Agar memiliki daya tarik dan informative, maka kemasan diberikan label. Label ini memuat nama produk, gambar produk, komposisi bahan, 
tanggal produksi dan tanggal kadaluarsa serta alamat produksi.

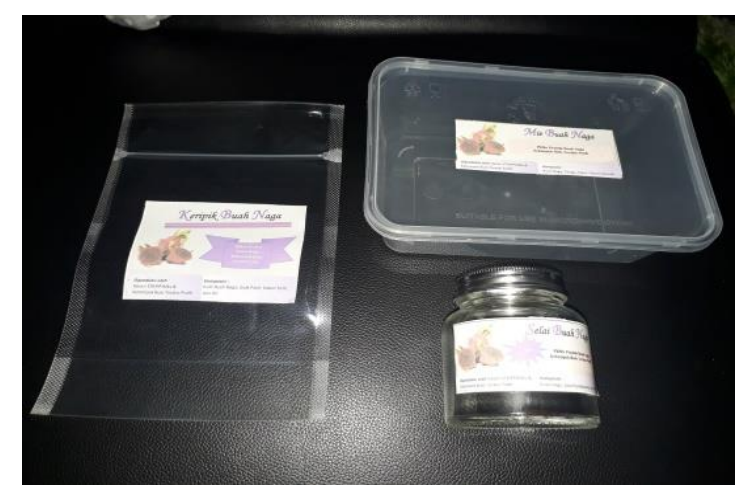

Gambar 6. Pengepakan dan Labelling

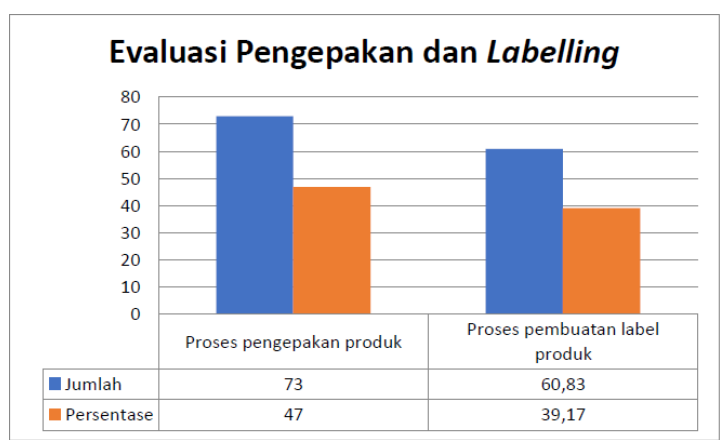

Grafik 3 : Hasil Evaluasi Pengepakan dan Labelling

Proses pengepakan (60,83\%) dan labeling $(39,17 \%)$, dari hasil evaluasi penilaian masyarakat memang agak kesulitan ditahap pembuatan label karena butuh alat dan kreativitas dalam merancang suatu label usaha.

\section{SIMPULAN DAN SARAN}

Pengolahan buah naga menjadi tiga jenis produk yaitu selai buah naga, mie buah naga dan keripik kulit buah naga merupakan produk yang memiliki nilai jual. Dalam proses pengolahaan buah naga, masyarakat berparsitipasi aktif dan kooperatif. Sementara, hasil pengolahan buah naga, produk selai buah naga memperoleh penilaian yang cukup tinggi dari masyarakat yaitu $40,91 \%$. Selain itu, masyarakat memperoleh pengetahuan tentang cara memilih kemasan produk dan cara pembuatan label produk.

Adapun saran yang dapat diterapkan dalam hal pengolahan buah naga adalah memaksimalkan cara pembuatan keripik buah naga dengan menggunakan mesin vacuum drying sehingga lebih gurih.

\section{DAFTAR RUJUKAN}

Andri Setiawan, A. S. (2017). Analisis Pendapatan Petani Buah Naga di Desa Sambirejo Kecamatan Bangorejo Kabupaten Banyuwangi. Jurnal Ilmu Ekonomi, 153-162.

Arikunto, S. (2011). Prosedur Penelitian : Suatu Pendekatan Praktik. Edisi Revisi VII. Jakarta: PT. Rineka Cipta.

Azwar, s. (2014). Reliabilitas dan Validitas, Edisi 4. Yogyakarta: Pustaka Belajar.

C. I., \& R. N. (2010). Teknologi Pengolahan Buah Naga dan Diversifikasi Produk Olahannya sebagai Upaya Peningkatan Jiwa Kewirausahaan di SMK Agri Industri. Jurnal Inotek, 15 (2).

Emil, S. (2011). Untung Berlipat dari Bisnis Buah Naga Unggul. Yogyakarta: Lili Publisher.

Hidayat, M. I. (2018). IBM Pengolahan Buah Naga sebagai Upaya Meningkatkan Nilai Tambah dan Pengendalian Harga Buah Naga di Kabupaten Tanah Lot. Jurnal Pengabdian Al-Ikhlas Universitas Islam Kalimantan Muhammad Arsyad Al Banjary, Vol 3 (2), 163-167.

Khairunnas, \& E, T. (2011). Analisis Kelayakan Usaha Tani Buah Naga di Pekanbaru. Jurnal Pendidikan Ekonomi dan Bisnis, Vol 3, No. 8, Hal 579-585.

Kristanto, D. (2008). Buah Naga Pembudidayaan di Pot dan Di Kebun. Jakarta: Penebar Swadaya.

Mahmudi. (2011). Pengolahan Pengetahuan Buah Naga, Budidaya dan Pemanfaatannya. Jakarta: Lembaga Ilmu Pengetahuan Indonesia.

Nurfahmiati, H. (2018). Pemberdayaan Masyarakat Melalui Program Badan Usaha Lorong ( Suatu Studi di Kecamatan Rappocini Kota Makassar). Makassar: Universitas Negeri Makassar. 
Caradde: Jurnal Pengabdian Kepada Masyarakat Vol 2 No 1, Agustus 2019

Rahmawati, M. (2013). Pengemasan dan

Pelabelan. Yogyakarta: Universitas

Negeri Yogyakarta. 